\title{
PENGARUH PENDAMPINGAN BELAJAR ORANG TUA TERHADAP HASIL BELAJAR MATEMATIKA SISWA KELAS V SD NEGERI SEKECAMATAN BUAYAN KABUPATEN KEBUMEN TAHUN AJARAN 2020/2021
}

\author{
Intan Aprilia' ${ }^{1}$, Wahyudi' ${ }^{2}$, Ratna Hidayah ${ }^{3}$ \\ Universitas Sebelas Maret \\ intan lili@student.uns.ac.id
}

\section{Article History}

accepted 1/11/2021

approved $1 / 12 / 2021$

published 31/12/2021

\begin{abstract}
The study aimed to determine the positive effect of parental assistance on mathematics learning outcomes to fifth grade students of public elementary schools in Buayan Sub-district in academic year of 2020/2021 and to measure the contribution of parental assistance on mathematics learning outcomes to fifth grade students of public elementary schools in Buayan Sub-district in academic year of 2020/2021. The research was a quantitative research with simple linear regression method. The samples were 306 fifth grade students in ten public elementary schools throughout Buayan Sub-district. Sampling method was probability sampling technique. The results showed that: (1) there is a positive and significant effect of parental learning assistance on the mathematics learning outcomes of fifth grade elementary school students in Buayan District with a regression of 0.266 with Sig. $0.000<0.05$, which means that the higher the learning assistance, the higher the learning outcomes of mathematics, and vice versa; (2) the effective contribution of the parental learning assistance variable to the mathematics learning outcomes of fifth grade elementary school students in Buayan District for the 2020/2021 academic year is $26.6 \%$ and the remaining $73.4 \%$ is influenced by other factors.
\end{abstract}

Keywords: parental assistance, mathematics learning outcomes

\begin{abstract}
Abstrak
Penelitian ini bertujuan untuk: (1) mengetahui adanya pengaruh positif pendampingan belajar orang tua terhadap hasil belajar matematika siswa kelas V SD Negeri se-Kecamatan Buayan pada Tahun Ajaran 2020/2021; (2) mengetahui besarnya sumbangan pendampingan belajar orang tua terhadap hasil belajar matematika siswa kelas V SD Negeri se-Kecamatan Buayan pada Tahun Ajaran 2020/2021. Penelitian ini merupakan penelitian kuantitatif dengan metode regresi linier sederhana dengan sampel penelitiannya yaitu 306 siswa kelas V SD di sepuluh SDN Se-Kecamatan Buayan yang dipilih secara acak dengan teknik probability sampling. Hasil penelitian menunjukkan bahwa (1) terdapat pengaruh positif dan signifikan pendampingan belajar orang tua terhadap hasil belajar matematika siswa kelas V SDN se-Kecamatan Buayan dengan regresi sebesar 0,266 dangan Sig. 0,000 $<0,05$, yang artinya semakin tinggi pendampingan belajar semakin tinggi pula hasil belajar matematika, begitupun sebaliknya; (2) sumbangan efektif variabel pendampingan belajar orang tua terhadap hasil belajar matematika siswa kelas V SDN se-Kecamatan Buayan tahun ajaran 2020/2021 sebesar 26,6\% dan sisanya $73,4 \%$ dipengaruhi oleh faktor lain. Berdasarkan hasil penelitian tersebut dapat disimpulkan bahwa terdapat pengaruh positif dan signifikan antara pendampingan belajar orang tua dan hasil belajar matematika siswa kelas V SDN se-Kecamatan Buayan tahun ajaran 2020/2021 dengan besarnyaa sumbangan $26,6 \%$. Hal tersebut menunjukan bahwa semakain tinggi pendampingan belajar orang tua, maka semakin tinggi pula hasil belajar matematika siswa.

Kata Kunci: Pendampingan Belajar, Hasil Belajar Matematika
\end{abstract}




\section{PENDAHULUAN}

Pendidikan merupakan upaya untuk membantu jiwa anak-anak didik baik lahir maupun batin, dari sifat kodratinya menuju kearah peradaban manusiawi dan lebih baik menurut Sujana (2019: 29). Dengan pendidikan manusia dapat menghadapi perkembangan zaman dengan lebih baik dibantu oleh pengetahuan yang sudah dimiliki. Pengetahuan diperoleh melalui proses belajar baik di sekolah maupun di rumah. Proses belajar mengajar yang dilaksanakan oleh guru dan siswa biasanya dilakukan di sekolah atau melalui interaksi langsung tanpa media perantara apapun. Namun pada saat ini proses pembelajaran mengalami perubahan, hal tersebut terjadi karena sebuah wabah yang menyerang seluruh dunia termasuk Indonesia yaitu Covid-19. Dampak wabah ini dalam pendidikan memunculkan kebijakan pemerintah Republik Indonesia berupa belajar dari rumah melalui pola pembelajaran daring.

Pembelajaran daring sangat berbeda dengan pembelajaran seperti biasa, menurut Riyana (Rahmawati, 2019:141) pembelajaran daring lebih menekankan pada ketelitian dan kejelian siswa dalam menerima dan mengolah informasi yang disajikan secara online. Pembelajaran daring membuat siswa belajar dengan mandiri untuk mempelajari semua mata pelajaran yang diberikan secara online. Salah satu mata pelajaran yang membutuhkan kemampuan berpikir logis dan berkaitan erat dengan berbagai aspek kehidupan yaitu mata pelajaran Matematika. Sejalan dengan pendapat Priatna (Riyanto dan Siroj, 2011: 113) mengemukakan bahwa kemampuan berpikir logis atau penalaran perlu dikembangkan dalam pembelajaran matematika, karena dapat membantu siswa untuk meningkatkan kemampuan pemahaman matematika.

Matematika adalah bahan kajian abstrak dan dibangun melalui proses penalaran yang didapat dari kebenaran suatu konsep sebagai akibat logis dari kebenaran yang sudah diterima, sehingga kebenaran antar konsep dalam matematika bersifat sangat kuat dan jelas, Wahyudi (2015: 68). Berdasarkan hasil penelitian Siregar (2017: 230) menyatakan bahwa Matematika merupakan pelajaran yang cukup sulit, namun demikian pelajaran Matematika penting untuk dipelajari. Kaharuddin (2018: 43) menyatakan bahwa "Mathematics is a universal science that underlies the development of modern technology, has an important role in advancing the power of human thought." Artinya matematika merupakan ilmu universal yang mendasari perkembangan teknologi modern, yang memiliki peran penting dalam memajukan daya pikir manusia. Meskipun matematika adalah pelajaran yang penting dalam kehidupan, namun sebagian besar siswa masih kurang termotivasi dalam belajar matematika. Mereka masih beranggapan bahwa matematika merupakan pelajaran yang sulit, sukar, dan menegangkan. Sejalan dengan hasil penelitian yang dilakukan oleh Meidya (2020; 49) terdapat hubungan yang signifikan antara persepsi siswa terhadap pembelajaran matematika dengan hasil belajar matematika yaitu sebesar $86,9 \%$. Sehingga persepsi siswa terhadap mata pelajaran matematika dapat menyebabkan hasil belajar yang diperoleh.

Hasil belajar merupakan tolok ukur keberhasilan siswa dalam mempelajari materi yang disampaikan selama periode tertentu menurut Feronita, dkk (2015: 257). Keberhasilan dari kegiatan belajar dapat diukur dari hasil belajar yang diperoleh. Hasil belajar merupakan suatu yang penting dalam pembelajaran, suatu kegiatan belajar dikatakan berhasil apabila hasil belajar siswa mencapai batas ketuntasan. Keberhasilan proses belajar matematika setiap anak berbeda. Hal itu disebabkan oleh beberapa faktor. Sobur (2010: 221) menyatakan faktor-faktor yang mempengaruhi belajar siswa 
terdiri dari faktor eksogen dan faktor endogen. Faktor endogen merupakan faktor yang berasal dari dalam diri individu meliputi dua, yakni faktor fisik dan faktor psikis. Faktor psikis meliputi inteligensi, perhatian dan minat, bakat, motivasi belajar, kematangan, dan kepribadian serta gaya belajar. Sedangkan faktor eksogen yaitu faktor yang bersumber dari luar diri individu seperti orang tua, guru, dan kondisi lingkungan di sekitar individu. Faktor orang tua meliputi perhatian pada anak, memahami kesulitan belajar anak, dan mendampingi belajar.

Orang tua memiliki peran mendampingi belajar anak untuk mengembangkan potensi yang ada di dalam diri siswa agar dapat menerima dan mengolah informasi. Pendampingan belajar berkaitan erat dengan proses dan hasil belajar anak, karena pendampingan diartikan bimbingan yang sifatnya lebih dekat dengan subjek yang dituju terutama dalam hal perkembangan belajar anak (Retno, 2013: 44). Pendampingan merupakan suatu aktivitas yang dilakukan melalui pembinaan, pengajaran, pengarahan dalam individu atau kelompok Yulianingsih, dkk (2020: 1145). Belajar merupakan satu faktor yang berperan penting dalam pembentukan pribadi dan perilaku individu (Abthoki, 2012: 170). Istilah pendampingan belajar berkaitan erat dengan proses dan hasil belajar anak, karena pendampingan diartikan bimbingan yang sifatnya lebih dekat dengan subjek yang dituju terutama dalam hal perkembangan belajar anak (Ambaryanti, 2013: 44). Seperti pada saat ini pembelajaran daring membutuhkan kerja sama orang tua untuk membimbing belajar di rumah. Membimbing anak belajar di rumah oleh orang tua artinya membantu perkembangan sikap, nilai, kebiasaan dan keterampilan yang mendorong keberhasilan siswa melalui kesediaan orang tua memotivasi anak sehingga berprestasi dalam belajar menurut Stainback (Sinaga, 2018: 44).

Ketercapaian hasil belajar yang baik tentunya diimbangi pula dengan adanya pendampingan belajar orang tua yang maksimal. Pendampingan yang maksimal adalah orang tua yang mendukung berlangsungnya proses belajar di rumah. Orang tua dapat mengatasi dan membantu kesulitan belajar siswa pada mata pelajaran matematika. Maka anak merasa semangat dan termotivasi untuk belajar dengan sungguh-sungguh. Dengan adanya kesadaran siswa untuk belajar pada akhirnya akan menghasilkan hasil belajar yang baik pula. Namun tidak semua orang tua dapat mendampingi belajar dengan maksimal. Berdasarkan survei pada 50 orang tua siswa didapatkan hasil bahwa sebesar $66 \%$ orang tua kurang maksimal dalam pendampingan belajar yang menyebabkan hasil belajar siswa rendah. Berdasarkan survei sebanyak $69 \%$ siswa mendapatkan hasil belajar matematika di bawah KKM. Sedangkan pendampingan belajar orang tua yang dilakukan secara maksimal sebesar $34 \%$ dan siswa mendapatkan hasil belajar di atas KKM sebesar $31 \%$.

Keterlibatan orangtua sangat penting karena memberikan pengaruh yang besar terhadap keberhasilan anak dalam prestasi belajar. Semakin intens pendampingan belajar orangtua kepada anak, maka hasil belajar yang diraihnya akan lebih baik, dan sebaliknya semakin kurang pendampingan yang dilakukan orangtua maka hasil belajarnya kurang baik pula (Retno, 2013:48). Hal ini menunjukkan bahwa orang tua diharapkan mendampingi belajar anak dengan optimal untuk mendapatkan hasil belajar yang baik. Selain itu, pendampingan orang tua secara optimal juga sangat membantu guru dalam menjalankan kegiatan belajar mengajar di sekolah. Apalagi pada saat ini pembelajaran yang dilaksanakan secara daring sehingga membutuhkan kerjasama antara guru dengan orang tua siswa. Adanya pendampingan orang tua di rumah dapat 
memudahkan proses belajar mengajar. Komunikasi antara orang tua dengan siswa juga sangat berpengaruh bagi keberhasilan belajar. Sejalan dengan pendapat Ambaryanti (2013: 44) menyatakan bahwa pendampingan yang diberikan oleh orang tua di rumah dapat meningkatkan motivasi belajar anak selain bimbingan dari seorang guru, dengan motivasi yang kuat seseorang sanggup bekerja ekstra keras dalam pencapaian sesuatu. Oleh karena itu, pendampingan belajar orang tua akan berpengaruh pada hasil belajar matematika siswa.

Berdasarkan uraian di atas, permasalahan dalam penelitian ini adalah untuk mengetahui adanya pengaruh positif pendampingan belajar orang tua terhadap hasil belajar matematika siswa kelas $\mathrm{V}$ di Kecamatan Buayan dan mengetahui besarnya sumbangan pendampingan belajar orang tua terhadap hasil belajar matematika siswa kelas $\mathrm{V}$ di Kecamatan Buayan melalui penelitian kuantitatif dengan judul "Pengaruh Pendampingan Belajar Orang Tua terhadap Hasil Belajar Matematika Siswa Kelas V SD Negeri Se-Kecamatan Buayan Kabupaten Kebumen Tahun Ajaran 2020/2021"

Tujuan penelitian ini adalah (1) mengetahui adanya pengaruh positif pendampingan belajar orang tua terhadap hasil belajar matematika siswa kelas $V$ SD Negeri se-Kecamatan Buayan pada Tahun Ajaran 2020/2021, (2) mengetahui besarnya sumbangan pendampingan belajar orang tua terhadap hasil belajar matematika siswa kelas V SD Negeri se-Kecamatan Buayan pada Tahun Ajaran 2020/2021.

\section{METODE}

Penelitian ini menggunakan desain penelitian kuantitatif dengan metode regresi. Analisis regresi menurut Bungin (2019: 231) adalah analisis persamaan garis yang diperoleh berdasarkan perhitungan statistika, umumnya disebut model untuk mengetahui bagaimana perbedaan sebuah variabel mempengaruhi variabel lain. Populasi penelitian ini adalah seluruh siswa kelas V SD di SDN Se-Kecamatan Buayan tahun ajaran 202/2021 yang berjumlah 950 siswa. Sampel penelitian ini berjumlah 306 siswa kelas V SD di sepuluh SDN Se-Kecamatan Buayan yang dilihat secara acak dengan teknik probability sampling jenis cluster random sampling. Sukardi (2012: 61) menyatakan bahwa, teknik klaster yaitu teknik pengambilan sampel yang didasarkan pada daerah atau kelompok subjek bukan didasarkan pada individual. SD yang digunakan dalam penelitian ini yaitu SDN 1 Sikayu, SDN 4 Sikayu, SDN 2 Mergosono, SDN 1 Nogoraji, SDN 2 Nogoraji, SDN 2 Rogodono, SDN Rangkah, SDN Adiwarno, SDN Karangsari, SDN Karangbolong.

Teknik pengumpulan data yang digunakan dalam penelitian ini yaitu menggunakan angket dan tes. Angket digunakan untuk mengumpulkan data pendampingan belajar orang tua dan tes digunakan untuk mengumpulkan data hasil belajar matematika siswa kelas V SD. Uji prasyarat data yang digunakan pada penelitian ini yaitu uji normalitas dan uji linieritas. Setelah data memenuhi perasyarat yang ditentukan, data akan dianalisis menggunakan analisis regresi, analisis korelasi, dan sumbangan efektif.

\section{HASIL DAN PEMBAHASAN}

Penelitian ini dilakukan dengan memberikan angket pendampingan belajar orang tua kepada orang tua dan siswa dan tes matematika kepada siswa di sepuluh SDN di Kecamatan Buayan. Angket berisi mengenai indikator-indikator yang berhubungan 
dengan pendampingan belajar orang tua sehingga dapat mengukur tinggi rendahnya pendampingan belajar orang tua terhadap anaknya khususnya dalam hal belajar. Tes berisi soal-soal yang memuat materi-materi matematika kelas $V$ SD sehingga dapat mengukur tinggi rendahnya hasil belajar matematika kelas $V \mathrm{SD}$. Uji prasyarat data penelitian ini terpenuhi yaitu data berdistribusi normal dan terdapat hubungan linier pendampingan belajar orang tua terhadap hasil belajar matematika siswa kelas V SD. Data hasil penelitian ini berasal dari data berdistribusi normal yang ditunjukkan dengan nilai signifikansi pendampingan belajar orang tua sebesar 0,200 dan nilai signifikansi hasil belajar matematika sebesar 0,200. Kedua nilai signifikansi tersebut menunjukkan nilai $>0,05$ sehingga data tersebut berasal dari populasi berdistribusi normal. Data hasil penelitian ini juga terdapat hubungan linier antara pendampingan belajar orang tua dan hasil belajar matematika kelas $\mathrm{V}$ SD yang ditunjukkan dengan nilai $p$ value Deviation from Linearity yaitu sebesar $0,088>0,05$, karena jika $p$ value Deviation form Linierity menunjukkan nilai $>0,05$ dapat dikatakan data tersebut terdapat hubungan linier antara variabel $x$ dan $y$.

Pengaruh pendampingan belajar orang tua terhadap hasil belajar matematika diuji menggunakan regresi linier sederhana. Analisis uji regresi linier sederhana menggunakan bantuan aplikasi Statistical Product and Service Solutions (SPSS) versi 21. Hipotesis yang digunakan yaitu $\mathrm{Ho}=$ tidak ada pengaruh positif antara pendampingan belajar orang tua dengan hasil belajar matematika siswa kelas $V$ SDN se-Kecamatan Buayan dan $\mathrm{Ha}=$ ada pengaruh positif antara pendampingan belajar orang tua dengan hasil belajar matematika siswa kelas V SDN se-Kecamatan Buayan.

Tabel 1 Data Pendampingan Belajar Orang Tua dan Hasil Belajar Matematika

\begin{tabular}{|c|c|c|c|c|}
\hline \multirow[t]{2}{*}{ No } & \multicolumn{2}{|c|}{$\begin{array}{c}\text { Pendampingan Belajar } \\
\text { Orang Tua }\end{array}$} & \multicolumn{2}{|c|}{ Hasil Belajar Matematika } \\
\hline & Interval & Frekuensi & Interval & Frekuensi \\
\hline 1. & $0-10$ & 0 & $0-10$ & 0 \\
\hline 2. & $11-20$ & 0 & $11-20$ & 0 \\
\hline 3. & $21-30$ & 0 & $21-30$ & 0 \\
\hline 4. & $31-40$ & 0 & $31-40$ & 2 \\
\hline 5. & $41-50$ & 0 & $41-50$ & 18 \\
\hline 6. & $51-60$ & 0 & $51-60$ & 45 \\
\hline 7. & $61-70$ & 36 & $61-70$ & 85 \\
\hline 8. & $71-80$ & 114 & $71-80$ & 85 \\
\hline 9. & $81-90$ & 121 & $81-90$ & 57 \\
\hline 10. & $91-100$ & 35 & $91-100$ & 14 \\
\hline
\end{tabular}




Total $306 \quad 306$

Tabel 2 Hasil Analisis Regresi Pendampingan Belajar Orang Tua Terhadap Hasil Belajar Matematika Siswa Kelas V SD

Model Summary

\begin{tabular}{lcccc}
\hline Model & $R$ & $R$ Square & Adjusted R Square & $\begin{array}{c}\text { Std. Error of the } \\
\text { Estimate }\end{array}$ \\
\hline 1 & $.516 a$ & .266 & .264 & 10.475 \\
\hline a. Predictors: (Constant), Pendampingan Belajar Orang Tua
\end{tabular}

Berdasarkan hasil pengujian koefisien regresi linier sederhana menunjukkan hasil bahwa nilai $\mathrm{t}$ hitung $=10,509>\mathrm{t}$ tabel $=1,967$ dan nilai signifikansi $0,000<0,05$, yang artinya Ho ditolak dalam arti lain pendampingan belajar orang tua berpengaruh signifikan terhadap hasil belajar matematika siswa kelas V SDN se-Kecamatan Buayan tahun ajaran 2020/2021. Hasil analisis tersebut juga menyatakan bahwa besarnya nilai koefisien korelasi $(R)$ yaitu sebesar 0,516 dan koefisien determinasi ( $R$ Square) sebesar 0,266 , yang artinya kontribusi pendampingan belajar orang tua terhadap hasil belajar matematika adalah sebesar $0,266 \times 100 \%=26,6 \%$, atau dengan kata lain $26,6 \%$ pengaruh hasil belajar matematika ditentukan oleh pendampingan belajar orang tua.

Berdasarkan penelitian dan perhitungan yang telah dilakukan, diketahui terdapat pengaruh positif pendampingan belajar orang tua terhadap hasil belajar matematika siswa kelas $\mathrm{V}$ SD. Oleh karena itu, semakin tinggi pendampingan belajar orang tua, maka semakin tinggi pula hasil belajar matematika siswa. Sebaliknya, semakin rendah pendampingan belajar orang tua, maka semakin rendah pula hasil belajar matematika siswa. Hal tersebut dikarenakan pendampingan belajar orang tua berkaitan dengan pendidikan anak yang dapat menunjang proses belajar anak di rumah yang meliputi memberikan motivasi belajar, mengawasi kegiatan belajar anak di rumah, membantu mengatasi kesulitan belajar anak, menyediakan fasilitas belajar, dan menentukan waktu belajar anak.

Pendampingan dilakukan dengan cara membantu mengerjakan tugas anak, sebagai tempat belajar anak, menerangkan dan memberikan penjelasan mengenai materi yang dipelajari, memberikan respon yang baik terhadap pembelajaran dari sekolah menurut Yulianingsih, dkk (2020: 1146). Pendampingan belajar orang tua yang dilakukan secara optimal akan berpengaruh pada hasil belajar anak. Dengan adanya pemberian pendampingan belajar oleh orang tua kepada anak secara maksimal, maka dapat meningkatkan motivasi belajar anak, membantu anak dalam mengatasi kesulitan belajar, memenuhi kebutuhan belajar, dan dapat meningkatkan hasil belajar anak.

Apabila indikator pendampingan belajar orang tua dapat dilaksanakan dengan maksimal maka akan berpengaruh terhadap hasil belajar anak. Hal tersebut sesuai dengan hasil penelitian Retno (2013: 48) semakin intens pendampingan belajar orangtua kepada anak, maka hasil belajar yang diraihnya akan lebih baik, dan sebaliknya semakin kurang pendampingan yang dilakukan orangtua maka hasil belajarnya kurang baik pula. Pentingnya pendampingan belajar orang tua juga dikemukakan oleh Sativa (Retno, 2013: 45) bahwa pendampingan orang tua dalam belajar anak sangat berpengaruh terhadap prestasi belajar. Pengawasan orang tua 
dalam belajar anak dirumah menyebabkan anak dapat belajar dengan penuh kedisiplinan.

Hasil perhitungan sumbangan efektif variabel pendampingan belajar orang tua terhadap hasil belajar matematika didapatkan sebesar $26,6 \%$, artinya pendampingan belajar orang tua berperan dalam meningkatkan hasil belajar matematika sebesar $26,6 \%$ dan sisanya $73,4 \%$ dipengaruhi oleh faktor lain, seperti: minat, bakat, kecerdasan, perhatian, motivasi, ketekunan, lingkungan sekolah, dan lingkungan masyarakat. Sejalan dengan pendapat Watimury \& Bahalwan (2019: 43) yaitu terdapat faktor lain yang dapat mempengaruhi hasil belajar khususnya hasil belajar matematika, terdiri dari faktor internal dan faktor eksternal. Faktor internal meliputi minat, bakat, kecerdasan, motivasi, perhatian, emosi, kesehatan jasmani, kemauan dan kesiapan belajar. Sedangkan faktor eksternal meliputi lingkungan keluarga, dan lingkungan masyarakat.

Hasil penelitian ini diperkuat dengan penelitian yang dilakukan oleh oleh Fadilah (2019: 7) yang berjudul "Pengaruh Pendampingan Orang Tua Terhadap Hasil Belajar Siswa Sekolah Dasar Kecamatan Cipatat" bahwa pendampingan belajar orang tua mempunyai pengaruh yang signifikan ditunjukkan dengan nilai uji F F-hitung 20,755 dan nilai uji $\mathrm{t}$ t-hitung 4,556 dan besaran pengaruh pendampingan orang tua terhadap hasil belajar yaitu sebesar $51,3 \%$. Sehingga dapat dinyatakan bahwa semakin baik pendampingan belajar orang tua terhadap siswa, maka semakin baik hasil belajar siswa tersebut. Sebaliknya, jika pendampingan belajar orang tua semakin berkurang, maka hasil belajar siswa akan semakin menurun.

\section{SIMPULAN}

Berdasarkan hasil penelitian dan pembahasan mengenai pengaruh pendampingan belajar orang tua terhadap hasil belajar matematika siswa kelas V SDN se-Kecamatan Buayan tahun ajaran 2020/2021 dapat ditarik kesimpulan sebagai berikut: (1) pendampingan belajar orang tua berpengaruh positif terhadap hasil belajar matematika siswa kelas V SDN se-Kecamatan Buayan tahun ajaran 2020/2021 dengan regresi sebesar 0,266 atau besarnya pengaruh yaitu $26,6 \%$ dan nilai t hitung $=10,509>$ $\mathrm{t}$ tabel $=1,967$ dan nilai signifikansi $0,000<0,05$, artinya semakin tinggi pendampingan belajar orang tua, maka semakin tinggi pula hasil belajar matematika siswa kelas V SDN se-Kecamatan Buayan tahun ajaran 2020/2021, (2) sumbangan pendampingan belajar orang tua terhadap hasil belajar matematika siswa kelas V SDN se-Kecamatan Buayan tahun ajaran $2020 / 2021$ sebesar $26,6 \%$ dan sisanya $73,4 \%$ dipengaruhi oleh faktor lain, seperti: minat, bakat, kecerdasan, perhatian, motivasi, ketekunan, lingkungan sekolah, dan lingkungan masyarakat.

\section{DAFTAR PUSTAKA}

Abthoki, A. (2012). Peran Ibu dalam Kegiatan Pendampingan Belajar Anak Melalui Prinsip Individual Learning-Centered. Jurnal Kesetaraan dan Keadilan Gender, 4 (2), $168-177$.

Ambaryanti, R. (2013). Hubungan Intensitas Pendampingan Belajar Orang Tua dengan Kualitas Hasil Belajar Siswa di RA Al-Islam Mangunsari 02 Semarang Tahun Pelajaran 2011/2012. Indonesian Journal of Early Childhood Education Studies, 2 (2), 43-49. 
Bungin, B. (2019). Metode Penelitian Kuantitatif. Jakarta: Prenadamedia Group.

Fadilah, E. R. (2019). Pengaruh Pendampingan Orang Tua Terhadap Hasil Belajar Siswa Sekolah Dasar. (Penelitian Deskriptif Kuantitatif dilakukan di SD Negeri Kecamatan Cipatat Kabupaten Bandung Barat). (Doctoral dissertation, FKIP UNPAS).

Feronita, A., Harnanik, H., \& Marimin, M. (2015). Pengaruh Keterampilan Mengajar Guru Dan Lingkungan Keluarga Terhadap Hasil Belajar Siswa (Studi Kasus Tentang Persepsi Siswa Pada Mata Pelajaran Surat Menyurat Kelas X Jurusan Administrasi Perkantoran Di Smk Palebon Semarang). Economic Education Analysis Journal, 4(2), 256-263.

Kaharuddin, A. (2018). Effect of problem based learning model on mathematical learning outcomes of 6th grade students of elementary school accredited B in Kendari city. International Journal of Trends in Mathematics Education Research, 1(2).

Meidya, A. (2020). Hubungan Persepsi Siswa Terhadap Mata Pelajaran Matematika Dengan Hasil Belajar Matematika Siswa Kelas V Sdn-1 Menteng Tahun Ajaran 2019/2020. Doctoral Dissertation, Universitas Palangka Raya.

Rahmawati, N.S., dkk. (2019). Analisis Pembelajaran Daring Saat Pandemi Di Madrasah Ibtidaiyah. Journal of Primary Education, 1 (2), 139-148.

Retno, (2013). Hubungan Intensitas Pendampingan Belajar Orang Tua dengan Kualitas Hasil Belajar Siswa di RA Al-Islam Mangunsari 02 Semarang Tahun Pelajaran 2011/2012. Indonesian Journal of Early Childhood Education Studies, 2 (2), 4349.

Riyanto, B., \& Siroj, R. A. (2011). Meningkatkan kemampuan penalaran dan prestasi matematika dengan pendekatan konstruktivisme pada siswa sekolah menengah atas. Jurnal Pendidikan Matematika, 5(2), 111-128.

Sinaga, J. D. (2018). Tingkat dukungan orang tua terhadap belajar siswa. Indonesian Journal of Educational Counseling, Vol. 2 No. 1 (2018), pp. 43-54. Yogyakarta: Universitas Sanata Dharma Program Studi Bimbingan dan Konseling. Diakses dari http://ijec.ejournal.id/index.php/counseling/article/download/19/22/ pada tanggal 22 September 2020

Siregar, N. R. (2017). Persepsi Siswa Pada Pelajaran Matematika: Studi Pendahuluan Pada Siswa Yang Menyenangi Game. Prosiding Temu IImiah X Ikatan Psikologi Perkembangan Indonesia, 224-232. Yogyakarta: Universitas Gadjah Mada.

Sobur, A. (2010). Psikologi Umum. Bandung: Pustaka Setia.

Sujana, I.W.C. (2019). Fungsi Dan Tujuan Pendidikan Indonesia. Jurnal Pendidikan Dasar, 4 (1), 29-39.

Sukardi. (2012). Metodologi Penelitian Pendidikan Kompetensi dan Praktiknya. Jakarta: PT Bumi Aksara. 
Wahyudi. (2015). Paduan Pembelajaran Matematika Sekolah Dasar. Surakarta: UNS PRESS.

Watimury, P., \& Bahalwan, F. (2019). Pengaruh Lingkungan Belajar Dan Konsep Diri Terhadap Hasil Belajar Biologi Siswa SMP Negeri I Maluku Tengah. Jurnal Biology Science \& Education, 8(1), 41-46.

Yulianingsih, W., dkk. (2020). Keterlibatan Orangtua dalam Pendampingan Belajar Anak selama Masa Pandemi Covid-19. Jurnal Pendidikan Anak Usia Dini, 5 (2), 11381150. 